IZA DP No. 5384

Evaluation of the Underground Economy in Quebec: A Microeconomic Approach

Bernard Fortin

Guy Lacroix

Dominique Pinard

December 2010 


\title{
Evaluation of the Underground Economy in Quebec: A Microeconomic Approach
}

\author{
Bernard Fortin \\ Laval University, CIRPÉE, CIRANO and IZA \\ Guy Lacroix \\ Laval University, CIRPÉE, CIRANO and IZA
}

Dominique Pinard

Statistics Canada

\section{Discussion Paper No. 5384 \\ December 2010}

\author{
IZA
}

P.O. Box 7240

53072 Bonn

Germany

Phone: +49-228-3894-0

Fax: +49-228-3894-180

E-mail: iza@iza.org

\begin{abstract}
Any opinions expressed here are those of the author(s) and not those of IZA. Research published in this series may include views on policy, but the institute itself takes no institutional policy positions.

The Institute for the Study of Labor (IZA) in Bonn is a local and virtual international research center and a place of communication between science, politics and business. IZA is an independent nonprofit organization supported by Deutsche Post Foundation. The center is associated with the University of Bonn and offers a stimulating research environment through its international network, workshops and conferences, data service, project support, research visits and doctoral program. IZA engages in (i) original and internationally competitive research in all fields of labor economics, (ii) development of policy concepts, and (iii) dissemination of research results and concepts to the interested public.
\end{abstract}

IZA Discussion Papers often represent preliminary work and are circulated to encourage discussion. Citation of such a paper should account for its provisional character. A revised version may be available directly from the author. 


\section{ABSTRACT}

\section{Evaluation of the Underground Economy in Quebec: A Microeconomic Approach}

The main purpose of this paper is to estimate the size and the growth of Quebec's underground economy, and the corresponding loss of taxes for the government. Our approach is based on a method developed by Pissarides and Weber (1989) and extended by Lyssiotou et al. (2004). The basic hypothesis is that individuals can under-report their earnings from self-employment but not from paid work, from which taxes are directly deducted. We estimate a consumer demand system in which the marginal propensity to consume is allowed to vary with the two types of earnings. We next estimate the amount of self-employment earnings that are under-reported. From this estimate, we calculate the relative size of the underground economy in Quebec. We use data from Statistics Canada's Survey of Household Spending. According to our results, Quebec's underground economy amounted to $4.6 \%$ of GDP in 1997 and increased slightly to $5.7 \%$ in 2002. For the government, this represents approximately $\$ 3.3$ billion in forgone taxes for the year 2002 . This estimate is very close to those reported by Gervais (1994) and Fortin and Lacroix (2009) using very different estimation methods and data.

JEL Classification: D12, E26, H26

Keywords: underground economy, demand system, household behavior, generalized method of moments, tax evasion, income from self-employment

Corresponding author:

Guy Lacroix

Department of Economics

Pavillon de Sève

Université Laval

Québec (Québec)

Canada G1K 7P4

E-mail: Guy.Lacroix@ecn.ulaval.ca

\footnotetext{
* We wish to thank Statistics Canada and the Quebec Inter-University Centre for Social Statistics (QICSS) for giving us access to annual data from the Survey of Household Spending for the period 1997-2002. We also thank the Centre Interuniversitaire sur le Risque, les Politiques économiques et l'Emploi (CIRPÉE), the Fonds québécois de la recherche sur la société et la culture (FQRSC), and the Canada Research Chair in Social Policies and Human Resources for their financial assistance. Finally, we are grateful to two referees for their very useful comments. This paper was first published in French as Bernard Fortin; Guy Lacroix et Dominique Pinard (2009), "Évaluation de l'économie souterraine au Québec, une approche micro-économétrique", Revue économique, 60 (5), pp. 1257-1274 @ Presses de Sciences Po.
} 


\section{Introduction}

The underground economy is a frequently overlooked, but very active, sector. It is usually defined as total earnings generated from the production of goods and services and concealed from government authorities. The underground economy is simply the very natural reaction of individuals seeking to evade the constraints and costs that the government imposes on exchanges in the form taxation, income security, and regulation. These individuals could do the same things legally by transferring their activities to official markets, but they prefer to go underground and transact on markets that parallel official markets.

The existence and growth of the underground economy raises a number of concerns. First, it may skew official statistics on the basis of which the socio-economic conditions of people and households are assessed (e.g. unemployment rate, poverty rate, GDP). Thus, statistics on the number of unemployed may conceal an unknown proportion who are, in fact, working on the black market and earning an income. These types of biases in the statistics may lead to flawed diagnoses and eventually to inappropriate policies.

Thus, issues raised by the underground economy relate to equity and social justice. In some sense, those who work under the table are comparable to stowaways: They are typically quite willing to consume government services, but shirk equitable participation in their funding. The result is diminished tax revenues to finance public goods and social transfers. The underground economy also affects economic efficiency. It favours a reallocation of resources toward sectors in which it is easier to cheat the taxman (e.g. renovation, childcare, housekeeping, professional services) at the expense of other sectors in which it is much more difficult to escape the watchful eye of authorities. Conversely, some underground activities may benefit society as a whole if they allow individuals to avoid regulation that is inefficient from an economic perspective or tax rates that are unduly burdensome.

The role played by the underground economy is clearly linked to its size. How extensive is it? The underlying problem we face is that, by its very nature, the underground economy is a difficult phenomenon to measure. Indeed, individuals who are active in it keep their participation secret to escape controls and penalties. Therefore, it is not surprising to find wide variations in estimates of the size of the underground economy, depending on the method used (Schneider and Enste, 2000).

For example, Mirus, Smith and Karleoff (1994) set the size of the underground economy in Canada at $27 \%$ of GDP in 1990, amounting to expenditures of nearly $\$ 18000$ per household. Their calculations are 
based on the monetary approach. This method is indirect and macroeconomic in nature. The underlying assumption is that black-market transactions are settled in cash. Consequently, an increase in the demand for cash over time in response to shifts in variables such as the tax rate provides information on the growth of the underground economy.

Using another macroeconomic method (the latent variable model), Giles and Tedds (2002) establish the size of the underground economy at $15 \%$ of GDP during the mid-1990s, for a mean average expenditure of $\$ 11000$ per household. This approach involves estimating a complicated model that links explanatory variables for the underground economy with some (observable) indicators of this activity. Applying a normalization rule and setting an initial value for the size of the underground economy for during the base year makes it possible to predict its evolution throughout the study period.

Based upon a detailed analysis of the national accounts, and postulating assumptions with respect to upper bounds on the relative size of the underground economy for each expenditure surveyed, Gervais (1994) concludes that the underground economy in Canada could not reasonably have exceeded 5\% of GDP in 1992.

Finally, Fortin et al. (1996) ${ }^{1}$ conduct a household survey of approximately 5000 individuals to assess the extent of the underground economy in Quebec. In contrast to previous approaches, this approach is direct and microeconomic in nature. According to their results, the black market-adjusted to account for the criminal economy — was less than 3\% of GDP in Quebec in 1993, or approximately \$2 000 per household. The authors believe that this measure is likely a lower bound on the magnitude of the phenomenon.

From this brief review of the literature for the post-1990 period, we see that assessments of the blackmarket economy in Canada and/or Quebec vary between 3\% and 27\%, depending on the methods used and the years examined. This extremely high variance in the results makes them difficult to use for analytical purposes. Thus, it is important to implement new and better estimation methods that will allow the variability in these measures to be reduced. That is the purpose of this article. We adopt an approach developed by Pissarides and Weber (1989) and recently generalized by Lyssiotou et al. (2004) to estimate the size of the underground economy in Quebec, along with its evolution between 1997 and 2002. The choice of this particular period is motivated by the availability of relevant data, the absence of significant changes to the

\footnotetext{
${ }^{1}$ Fortin and Lacroix (2009) present an analysis of the principal results of this study.
} 
Canadian tax regime, and the desire for comparability with other studies covering similar periods.

The approach developed by these authors uses a household expenditure model. It involves estimating an expenditure system as a function of household income from various sources and other explanatory variables. Thus, the approach is based on principles underlying standard consumer theory. Moreover, we assume that income from employment is fully declared, since the associated taxes are usually withheld at the source. However, we assume that net income from self-employment may be under-declared (either by overstating costs or by understating gross income). If this is the case, and if we assume that for each consumed good the propensity to consume is uncorrelated with the income source, it is possible to identify a coefficient of under-declaration of income from self-employment. The estimated coefficient can be used to generate a measure of the share of the underground economy in GDP from the relative weight of income accruing from self-employment.

It is important to emphasize that this procedure does not fully eliminate the problem of underestimating incomes caused by under-declaration for two reasons. On one hand, in the case of self-employed workers who engage in legal work but conceal all of their income, the coefficient of underreporting will apply to an income of zero. Thus, we will underestimate their concealed income and, by extension, the size of the underground economy. On the other hand, the extent of the phenomenon will also be underestimated because survey data do not cover illegal activities, such as drugs, gambling, and prostitution.

While the Pissarides and Weber (1989) approach is based on estimation of a single demand equation (food), its generalization by Lyssioutou et al. (2004) involves estimating a demand system on nondurable goods. This is the approach we use. Ideally, we would have liked to compare the results generated by this model with those from other approaches, such as the monetary approach or the latent variable model. However, one of the indicators required for these methods, the money stock, is not available at the provincial level, rendering them inoperable.

We use the generalized method of moments (GMM) to estimate a system of expenditures on six nondurables (expressed as shares of total spending on nondurables) in a quadratic formulation with logged household income and other explanatory variables. The data used are from Statistics Canada's Survey of Household Spending for the period from 1997 to 2002.

The article is structured as follows. Section 2 presents the theoretical model retained for purposes of 
estimation. Section 3 discusses the data used. Section 4 describes the econometric method as well as the estimation results. Section 5 presents our evaluation of the size of the underground economy and its recent growth, as well as the tax leakage it imposes on the provincial government. Section 6 concludes.

\section{The Theoretical Model}

The model we use to estimate the size of the underground economy in Quebec builds on two sets of hypotheses. The first set relates to the consumer expenditure system used to estimate the model. The second yields an assessment of the size of the underground economy and deals with assumptions about the truthfulness of income tax and household expenditure declarations.

\subsection{The consumer expenditure system}

We assume that household preferences are characterized by implicit, or quasi, separability in nondurable and durable goods (Deaton and Muellbauer, 1980). The advantage of this assumption is that Hicksian demand for any nondurable good, expressed in terms of its share of total expenditures on nondurable goods, will only depend on the prices of nondurable goods and total utility. Thus, replacing the indicator of utility with the indirect utility function in this equation, and assuming that relative prices are constant (one of our hypotheses), Marshallian demand in corresponding shares only depends on total household income. This is the type of system on shares of nondurables that we estimate.

More formally, the implicit separability assumption implies that the household cost function can be written: $C=C[c(\mathbf{p}, U), d(\mathbf{s}, U), U]$, where $\mathbf{p}$ and $\mathbf{s}$ are, respectively, price vectors for nondurable and durable goods, and $U$ is the indicator of total utility. The functions $c(\cdot)$ and $d(\cdot)$ represent aggregate price indices for nondurable and durable goods. Each of these functions is increasing in $U$ and linearly homogeneous in its price subvector. This structure implies that household consumption decisions can be decomposed into two stages (two-stage budgeting). In the first stage, the household allocates its total income $\left(Y^{*}\right)$ to expenditures on nondurable and durable goods as a function of $c(\cdot), d(\cdot)$ and $U$, so as to minimize costs. In the second stage, the household allocates spending on each group (nondurable or durable goods) among its various goods as a function of the vector of prices in this group and the total level of utility.

More precisely, let $q_{i}$ represent the quantity of the nondurable good $i$ purchased by the household. Total 
expenditures on nondurable goods can thus be written:

$$
y=\sum_{i} p_{i} q_{i}=\frac{\partial C(\cdot)}{\partial c} \sum_{i} p_{i} \frac{\partial c(\cdot)}{\partial p_{i}}=\frac{\partial C(\cdot)}{\partial c} c(\cdot)
$$

using Shepherd's lemma and the property of linear homogeneity in $\mathbf{p}$ of function $c(\cdot)$. The portion $\left(w_{i}\right)$ of total expenditures on nondurables devoted to nondurable good $i$ is given by:

$$
w_{i}=\frac{p_{i} q_{i}}{y}=\frac{p_{i} \frac{\partial C(\cdot)}{\partial c} \frac{\partial c(\cdot)}{\partial p_{i}}}{\frac{\partial C(\cdot)}{\partial c} c(\cdot)}=\frac{p_{i} \frac{\partial c(\cdot)}{\partial p_{i}}}{c(\cdot)}=\frac{\partial \ln c(\cdot)}{\partial \ln p_{i}}
$$

or:

$$
w_{i}=w_{i}(\mathbf{p}, U),
$$

with $\sum_{i} w_{i}=1$ and $w_{i}(\cdot)$ being homogeneous of degree zero in $\mathbf{p}$. Equation (3) gives Hicksian expenditure shares for nondurables. To obtain a functional form for these shares, we first need to specify a functional form for $c(\mathbf{p}, U)$. As suggested by Lewbel (1990), we approximate this function with an exponential form containing a term for the interaction between the utility level and a price function:

$$
c(\mathbf{p}, U)=\exp \left\{a(\mathbf{p})+b(\mathbf{p})\left[\frac{U}{1-g(\mathbf{p}) U}\right]\right\}
$$

where the functions $a(\mathbf{p}), b(\mathbf{p})$ and $g(\mathbf{p})$ are linearly homogeneous in $\mathbf{p}$.

Taking the log of this function, we obtain:

$$
\ln c(\mathbf{p}, U)=a(\mathbf{p})+b(\mathbf{p})\left[\frac{U}{1-g(\mathbf{p}) U}\right]
$$

Finally, using (2), the equation for Hicksian shares takes the following form:

$$
w_{i}=a_{i}(\mathbf{p})+b_{i}(\mathbf{p})\left[\frac{U}{1-g(\mathbf{p}) U}\right]+\lambda_{i}(\mathbf{p})\left[\frac{U}{1-g(\mathbf{p}) U}\right]^{2},
$$

where $a_{i}(\mathbf{p})=\frac{\partial a(\mathbf{p})}{\partial \ln p_{i}}, b_{i}(\mathbf{p})=\frac{\partial b(\mathbf{p})}{\partial \ln p_{i}}$ and $\lambda_{i}(\mathbf{p})=b(\mathbf{p}) \frac{\partial g(\mathbf{p})}{\partial \ln p_{i}}$.

Equation (6) cannot be directly estimated because the indicator of utility is not observable. However, replacing $U$ with the indirect utility function $V=V\left(\mathbf{p}, \mathbf{s}, Y^{*}\right)$ in this system, we obtain the following expression 
for Marshallian shares during the base period, with $\mathbf{p}=\mathbf{s}=1$, (see Lyssiotou et al., 2004):

$$
w_{i}=\alpha_{i}+\beta_{i}\left[\ln Y^{*}\right]+\delta_{i}\left[\ln Y^{*}\right]^{2} .
$$

where $\alpha_{i}, \beta_{i}$ and $\delta_{i}$ are parameters. Equation (7) represents quadratic Engel curves on logged total income and expressed in shares of total expenditures on nondurables. This functional form generalizes the WorkingLeser formulation (cf. Deaton and Muellbauer, 1980), which omits the quadratic term. This is very useful because it allows a good to be a necessity at some levels of income and a luxury at others. In addition, Bank et al. (1997) laid rigorous theoretical and empirical foundations for this functional form for Engel curves. In particular, they derived the complete class of expenditure share systems that are integrable and quadratic in logged income.

In our analysis we ignore variations in relative prices for two reasons. First, there are no province-level price indexes for the groups of goods we use in our analysis. Also, the analysis covers a relatively short period (1997-2002). However, we incorporate general increases in the price level by deflating income with a consumption price index. Furthermore, we allow the constant in the Engel curves to vary from one year to the next.

\subsection{Assumptions regarding households' declarations}

For purposes of estimating the Engel curves (7) and assessing the size of the underground economy, it is necessary to make certain assumptions regarding income and household expenditures as they are declared and reported in surveys.

First, we assume that people truthfully report their profile of consumption expenditures on nondurables. The rationale behind this assumption is that there are no incentives for households to misrepresent their expenditure profile ${ }^{2}$ because, in general, they will not be penalized for illegal transactions. Using expenditures on nondurable goods as endogenous variables strengthens this assumption. In fact, this type of good is not an asset, and therefore cannot be accumulated. It is consumed in the short term, and amounts consumed in the past have little relevance.

\footnotetext{
${ }^{2}$ In a Gallup survey (1993), 33\% of respondents admitted to having paid for a good or service in cash in order to avoid paying sales taxes during the previous twelve months.
} 
Household income can be from two sources: Wages earned from a job and earnings from self-employment. Other income consists mostly of transfers from government. For purposes of this study, we assume that wage earners have to declare all of the income they receive from their employer-a reasonable assumption, we think. However, the self-employed may have an incentive to conceal some of their earnings from self-employment, i.e. under-declare it in order to evade part of their fiscal obligations. This assumption is fundamental to our model. As to other sources of income, we assume that they are also declared in full.

Thus, our model provides an estimate of the proportion of income from self-employment that is underdeclared. A simple illustration of the procedure is as follows. Assume two individuals are economically identical and declare the same total income. The only difference between them is that the fist earns his income from self-employment, while the second earns hers from a job. We observe that the share of luxury items (which have an income elasticity greater than one) in expenditures is higher for the former than for the latter. The employee, consequently, devotes a greater share of her expenditures to necessities (which have an income-elasticity less than one). We conclude that the former under-declares some of his earnings from self-employment. Statistically, we need to estimate the rate of under-declaration of income from selfemployment, allowing us to fully predict the different consumption profiles of the two individuals using the Engel curve. Subsequently, extrapolating from under-declared self-employment earnings to the entire population will reveal the extent of the underground economy relative to the total economy.

More formally, we begin by disaggregating actual household income into its three sources:

$$
Y^{*}=\sum_{m=w, s, o} \theta_{m} Y_{m}
$$

where $w, s$, and $o$ are indices identifying the wage, self-employment earnings, and income from other sources (e.g. government transfers), $Y_{m}$ is declared income from source $m$, and $\theta_{m}$ is the scaling factor by which declared income from source $m$ must be multiplied to obtain its actual value. This parameter is greater than or equal to unity $\left(\theta_{m} \geq 1\right)$. Assuming that wages and other income are fully declared, we have $\theta_{w}=\theta_{o}=1$. Conversely, since income from self-employment may be under-declared, $\theta_{s}$ must be greater than or equal to unity $\left(\theta_{s} \geq 1\right)$. If we wish to impose this constraint on econometric estimates, the expression for the parameter $\theta_{s}$ will be given by $[\exp (\kappa)+1]$, where $\kappa$ is the parameter estimated by the model. The income from self-employment that is actually earned $\left(Y_{s}^{*}\right)$ thus becomes $[\exp (\kappa)+1] \times Y_{s}$. Moreover, this 
parameter interacts with a linear and a squared trend in order to capture the evolution of the underground economy between 1997-2002. The parameter $\kappa$ thus becomes a function of time: $k_{1} \times t+k_{2} \times t^{2}$, where $t$ corresponds to the trend between 1997 and 2002.

In the model, the shares of income from self-employment $(m=s)$, wages $(m=w)$, and other $(m=o)$ are rewritten as the ratio of each of these amounts to total reported income: $y_{m}=Y_{m} / Y$. After replacing total income by its components and using the properties of logs, equation (7) takes the following form:

$$
w_{i}=\alpha_{i}+\beta_{i}\left[\ln Y+\ln \left(\sum_{m=w, s, o} \theta_{m} y_{m}\right)\right]+\delta_{i}\left[\ln Y+\ln \left(\sum_{m=w, s, o} \theta_{m} y_{m}\right)\right]^{2},
$$

with $\theta_{w}=\theta_{o}=1$.

In order to account for observed heterogeneity in preferences, we introduce a vector of household characteristics $(z)$ into the econometric model. The choice of characteristics will be presented below. It draws on the work of Pissarides and Weber (1989) and Lyssiotou et al. (2004). However, this choice is limited by the availability of variables in the database. ${ }^{3}$

In addition, we must allow individuals with self-employment earnings to adjust consumption choices to fluctuations in income differently from other households. The typically greater degree of uncertainty they experience suggests that they may make decisions differently than would those receiving a wage, for example. For this reason, in line with Lyssiotou et al. (2004), we introduced a cubic expression into each demand equation to reflect the relative weight of earnings from self-employment in the household's total income $\left[\sum_{l=1}^{3} \delta_{i l}\left(y_{s}\right)^{l}\right]$. This expression serves to reduce the likelihood of confusing heterogeneity in consumption with the phenomenon of under-declaring income from self-employment. We observe that the coefficient of under-declaration is identifiable because it appears in the linear and quadratic parts representing the impact of "real" household income on expenditure shares. The cubic expression we add to the model as part of the relative weight of self-employment earnings is not directly affected by $\theta$ and has a natural interpretation as a factor of heterogeneity observed in consumption choices.

The system of nondurable-good expenditure shares consists of six equations for the following categories: food, alcoholic beverages, clothes, transportation, personal care, and recreation. Because of the adding-up constraint, the last category is omitted from the estimations. Appendix 1 presents the definition of the

\footnotetext{
${ }^{3}$ Our database contains no information on education level or profession.
} 
different consumption expenditure variables used in the model.

\subsection{Computing the size of the underground economy}

The size of the underground economy is calculated from the parameter $\theta_{s}$. As we saw on page 7, it is given by:

$$
\begin{aligned}
\theta_{s}(t) & =\exp (\kappa)+1 \\
& =\exp \left(\kappa_{1} \times t+\kappa_{2} \times t^{2}\right)+1
\end{aligned}
$$

To determine the size of the underground economy, we must allocate annual GDP to income from selfemployment $\left(Y_{s}\right)$, from wages $\left(Y_{w}\right)$, and from other sources $\left(Y_{o}\right)$. Aggregating $\left(Y_{w}\right)$ and $\left(Y_{o}\right)$ allows us to write:

$$
\mathrm{ES}(t)=\frac{Y_{w o}(t)}{Y(t)}-\theta_{s}(t) \times \frac{Y_{s}(t)}{Y(t)}-100 \%
$$

where $\mathrm{ES}(t)$ is the estimated share of GDP that is undeclared, and $Y_{w o}(t)=Y_{w}(t)+Y_{o}(t)$.

\section{The Data}

Our data is from Statistics Canada's Survey of Household Spending (SHS), 1997 to 2002. The SHS has proven to be a very useful database because it contains pertinent information on Canadian households. ${ }^{4}$ The survey is designed to gather information about consumption habits and income sources as well as individual characteristics (age, type of union, household composition, residence, appliances, etc.) of households. ${ }^{5}$

Moreover, the estimation only covers the period 1997 to 2002, despite the availability of relevant information for a longer period. In fact, from 1974 until 1996, Statistics Canada conducted a survey similar to the SHS approximately every four years: the Family Expenditure (FAMEX) Survey. However, for reasons of efficiency, Statistics Canada replaced FAMEX with the SHS, which combines information on households

\footnotetext{
${ }^{4}$ The SHS covers households in all ten provinces and three territories. For the estimation we only used information on Quebec households.

${ }^{5}$ However, to access this data we had to make a special request to the Social Sciences and Humanities Research Council of Canada (SSHRC), because the level of disaggregation required for the estimates was not available in the public data. In light of the confidentiality of the composition of total income, the actual estimations were run in the offices of the Quebec Inter-University Centre for Social Statistics (QICSS) in Montreal.
} 
with data from the Household Facilities and Equipment Survey (HFE). Both the SHS and FAMEX contain variables required for estimating the model. However, since the definitions of the variables in the FAMEX vary from one year to the next, data gathered before 1997 are not usable.

In a cross-section, the SHS does not provide information on enough households to estimate the model (on average, 1070 households per year, of which approximately 10\% have income from self-employment). Consequently, we opted to use stacked data from the six years of the survey. This gave us a total of 6451 households.

We imposed several constraints on the underlying data in order to make the sample more homogeneous. Thus, the retained households are married couples with or without children. In addition, households in which the age of the respondent was 70 or above were excluded. Households having declared negative income (from self-employment or wages) were also eliminated, as were those reporting a total gross income that was negative, nil, or greater than $\$ 400000$. Finally, the household was also dropped if the ratio of self-employment earnings to total income, and/or wage earnings to total income, exceeded one.

The sample contains 7082 households, of which 631 (or 9\% of the total) were self-employed. ${ }^{6}$ On average, they consist of two adults and 1.2 children ( 0 to 24 years old, but mostly under 16$)$. From the average income and expenditures presented in Table 1 we see that, for a given level of income as reported in the survey, the current expenditures ${ }^{7}$ of households of self-employed workers exceed the global average. This finding lends support to our hypothesis that independent workers tend to under-declare their incomes.

\section{Results of the Estimation}

In order to estimate the parameter of interest, we used the generalized method of moments (GMM). This method is appropriate for estimating a function that is nonlinear in the parameters and with endogeneity of some explanatory variables. In our model, variables for income are assumed endogenous. After several tests that revealed the presence of weak instruments, we pared them down to the following: ${ }^{8}$ the age of the

\footnotetext{
${ }^{6}$ We consider the members of a household to be self-employed if more than $25 \%$ of total household income is from selfemployment.

${ }^{7}$ Current expenditures include spending during the survey year on food, housing, household operation, household furnishings and equipment, clothing, transportation, health care, personal care, recreation, reading materials and other printed matter, education, tobacco products and alcoholic beverages, games of chance, and miscellaneous.

${ }^{8}$ Weak instruments were detected with the standard $F$-test of joint equality to zero of the coefficients of the instruments in GMM estimations of different income sources on the instruments and the exogenous explanatory variables (See Stock et al., 2002).
} 
reference person in levels, squared, and cubed, the marital status of the household, the sex of the reference person, the number of children between 0 and 15, the place of residence (a function of the population), interaction between age and place of residence, interaction between spouse's age and the number of children between 0 and 15 years, interaction between the age of the reference person and marital status.

In addition, the control variables included in the model are as follows: the household reference year, the number of children between 15 and 24, the age of the reference person's spouse, the place of residence (rural or urban), the number of rooms in the principal residence, automobile ownership, and the housing tenure for the principal residence (rented or owned).

Table 2 presents estimation results for the demand system. First, we note that the Sargan-Hansen test statistic of 42.2 validates the choice of instruments, being below the critical chi-square value at the $5 \%$ level for 30 degrees of freedom (43.8).

The typology of goods resulting from the model diverges somewhat from the results in Deaton and Muellbauer (1980). To estimate their demand system from 1900 to 1970, they use a symmetric version of the Rotterdam model for the United Kingdom. Thus, they treat food, housing costs, transportation and communications, recreation, and services all as necessities. Conversely, our results suggest that food and personal care are luxuries (for incomes below a critical level), while all other goods are necessities (also for incomes below a critical level). One explanation for these results is that definitions of goods vary from one study to the next.

In addition, looking at the time dummy we find that, unlike the shares of food and clothing, those of alcohol, transportation, and personal care in expenditures on nondurables increase over time. We note, however, that only some of the coefficients associated with clothing and personal care (and one coefficient for transportation) are significant, which corroborates our assumption that relative prices remained relatively stable during this period.

Also, households in which the share of income from self-employment in total income is relatively high appear to spend less on clothing than other households, ceteris paribus. Finally, as we might expect, automobile ownership is positively correlated with expenditures on transportation. We conclude that, in general, estimation results for the expenditure system are consistent and intuitive.

Estimation of the underground economy proceeds from the model's parameters ( $\kappa$ ) (cf. Section 2.2, page 
7), found at the bottom of Table 2. The coefficients of trend and trend squared are significant at 5\%. They are used to calculate the annual scaling factor $\theta_{s}$, which in turn is multiplied by declared self-employment earnings to obtain their true values.

\section{Size of the underground economy and tax leakage}

\subsection{Estimation of the size of the underground economy}

Estimating the relative weight of the underground economy in GDP requires additional information on the level of income from self-employment in Quebec's GDP. According to Statistics Canada, during the period from 1997 to 2002 an average of 6.0\% of Quebec's GDP was from self-employment, while the corresponding number for Canada was 6.4\%. As we see in Tables 3 and 4, these proportions remained fairly constant throughout the years of our study. On the basis of the numbers for Quebec and the estimated coefficients for $k_{1}$ and $k_{2}$, and using the method presented in Section 2.3, we can extrapolate the size of the

underground economy from Quebec's GDP. The results are presented in Table 5 and illustrated in Figure 1. They suggest that the underground economy represented approximately $4.6 \%$ of GDP in 1997 and $5.7 \%$ of GDP in 2002, for a 23\% growth. On average, the three million plus households in Quebec would have spent a little over \$4 300 on the black market in 2002 .

As we mentioned in the introduction, our measure of the underground economy probably understates its size, since it omits criminal activities such as drugs, gambling, and prostitution. If the estimate in Gervais (1994) (that these activities amount to 1\% of Canada's GDP) proves to be a good approximation for Quebec in 2002, the size of the underground economy including criminal activity was $6.7 \%$ of GDP at that time. However, police forces appear to believe that these activities have been expanding in recent years, and that Quebec is above the national average. An assessment of the criminal economy in Quebec should be the subject of future work.

\subsection{Estimation of tax losses to the government of Quebec}

The main purpose of this study is to assess the size of the underground economy. The estimates also allow us to approximate the associated tax revenue lost to the government of Quebec. According to our results, 
GRAPHIQUE 1: Size of the underground economy

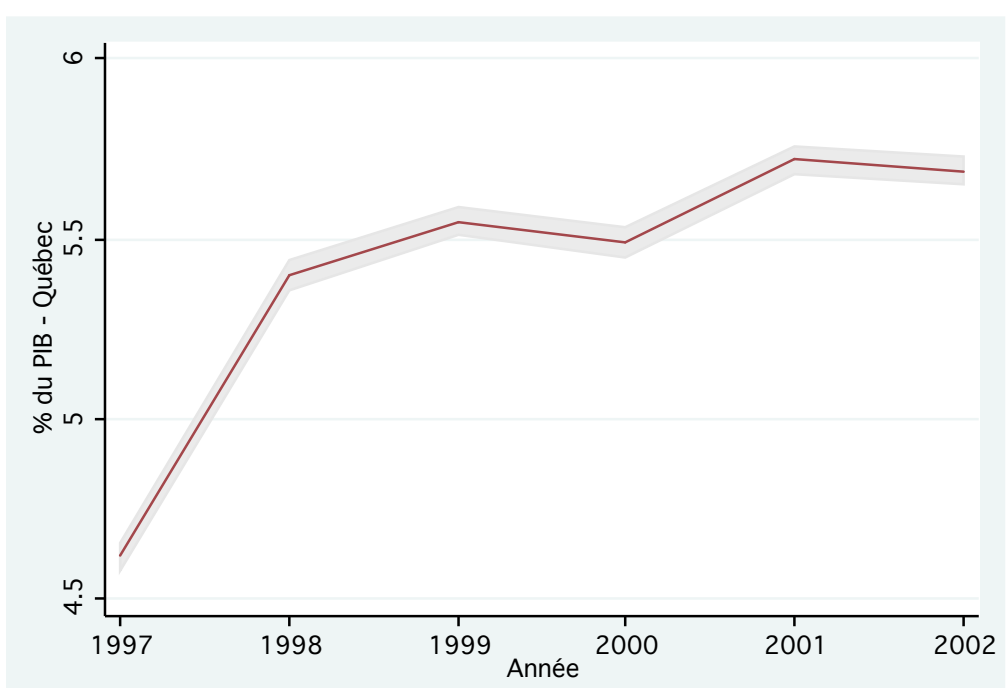

Notes: Voir Tableau 5. Partie ombagée $=$ Intervalle de confiance

the underground economy represents an average of 5.4\% of GDP during the period of the study-in other words, on average it generates $\$ 12$ billion annually in self-employment earnings. Tax leakage can then be computed using the rate of taxation of goods and services and the income tax schedule. The Quebec Sales Tax (QST) remained constant at 7.5\% between 1997 and 2002. Since self-employed workers can obtain reductions on their tax burden, and since Quebec's income tax system is progressive, not all individuals are taxed at the same rate. ${ }^{9}$ Therefore, using information on taxes paid from the SHS, we need to extrapolate a mean annual tax rate for self-employed workers. Here we use taxes paid by households and estimate an average for total income. It should be borne in mind that this tax leakage is from productive activities that are legal but performed illegally. Concealed non-productive or illegal activities, such as fraudulent claims for tax returns or for unearned credits, are not included in this research, but they may appear in part in the estimation via the calculation of the mean tax rate.

As we see in Table 7, from 1999 on the level of tax leakage has hovered near $\$ 3.3$ billion. However, this does not reflect the evolution of the underground economy. This stability is primarily attributable to

\footnotetext{
${ }^{9}$ The progressiveness of the income tax system gives rise to some methodological problems. Hours of work, the choice between wage work and self-employment, and under-declaration of income from self-employment may all be influenced by the progressiveness of the income tax system. A thorough accounting for the tax system would make the econometric specification of the model unduly cumbersome. In keeping with previous work (Lyssiotou et al., 2004; Pissarides and Weber, 1989) we omit this dimension from the analysis, though remaining aware that our results must be interpreted with this limitation in mind.
} 
the decline in the tax rate, which fell from $17.7 \%$ in 1999 to $15.5 \%$ in 2002 . Tax leakage attributable to underground activity represented a little less than $9 \%$ of sales and income taxes collected by the government of Quebec for the fiscal year 2002. ${ }^{10}$

\section{Conclusion}

As we have already mentioned, several methods for estimating the size of the underground economy have been proposed in the literature. However, owing to the unavailability of data on certain variables, such as the demand for liquid money, most of these approaches cannot be applied to Quebec. In light of this, we implement a microeconomic approach that appears promising. It is based on consumer choice theory and the tendency of individuals to under-declare income from self-employment.

The model used to evaluate the size of the underground economy first seeks to explain household consumption expenditure shares in terms of the proportion of nondurables consumed by income source and other explanatory variables. Five expenditure items are analysed: food, alcohol, transportation, clothing, and personal care. The estimations use instruments to account for the endogeneity of the sources of income. The econometric approach used to perform the estimation is the generalized method of moments.

Our data is from the Survey of Household Spending (SHS) conducted by Statistics Canada every year since 1997. The most recent data are from the 2002 SHS. This database provides a breakdown of income, many household characteristics, and expenditures. We observe that, on average, for a given level of income, the current expenditures of households of self-employed workers are higher than the overall mean. This finding is consistent with the assumption that, on average, the self-employed under-declare some fraction of their income.

According to our results, Quebec's underground economy represented 4.6\% of GDP in 1997, and increased slightly to $5.7 \%$ in 2002. On average, in 2002, Quebec households thus spent $\$ 4300$ in the underground economy. Our study nevertheless suggests that the size of the underground economy in Quebec, though greater than the conservative estimates yielded by the survey approach (3\% of GDP for 1993, ac-

\footnotetext{
${ }^{10}$ The fiscal year 2002 begins on April 1, 2002 and ends on March 31, 2003. Income from sales and income taxes includes personal income taxes, the Fond des services de santé, corporate income tax, consumption taxes, and other income, as well as revenues generated by government-owned businesses. It amounted to $\$ 41.2$ billion in the fiscal year 2002 (Ministère des Finances du Québec, 2004).
} 
cording to Fortin et al., 2009) is well below those obtained from indirect macroeconomic methods such as the latent variables model. According to the latter, the underground economy would amount to over $15 \%-$ 16\% of Canadian GDP in 1995 (Giles and Tedds, 2000, and Schneider and Enste, 2000). Our estimates are statistically very precise and coincide almost perfectly with the 5\% upper bound established for Canada by a Statistics Canada study for the year 1992 (Gervais, 1994). It thus seems reasonable to assume that the share of the underground economy is very likely to amount to no more than 5\% of GDP. 


\section{References}

[1] Bank, James, Richard Blundell and Arthur Lewbell, (1997), Quadratic Engel Curves and Consumer Demand, The Review of Economics and Statistics, Vol. LXXIX, no 4., pp. 527-539.

[2] Deaton, Angus and John Muellbauer, (1980), Economic and Consumer behavior, Cambridge University Press, United States, 450 pp.

[3] Fortin, B., G. Garneau, G. Lacroix, T. Lemieux, C. Montmarquette,(1996), L'économie souterraine au Québec, Mythes et réalités, Ste-Foy, Les Presses de l'Université Laval.

[4] Fortin, B. and G. Lacroix, (2009), "Informal Work in Canada," in Informal Work in Developed Nations, ed. E. Marcelli, C. C. Williams, and P. Joassart, chap. 14. Routledge.

[5] Gervais, Gylliane, (1994) The Size of the Underground Economy in Canada, Statistics Canada, No. 13-603F, Catalogue no. 2.

[6] Giles, David E. A. and Lindsay M. Tedds, (2000), Taxes and the Canadian Underground Economy, Canadian tax paper, no.106.

[7] Lewbel, Arthur (1990), Full Rank Demand System, International Economic Review, 31, pp. 289-300.

[8] Lyssiotou, Panayiota, P. Pashardes and T. Stengos, (2004), Estimates of the Black Economy Based on Consumer Demand Approaches, , The Economic Journal, 114, pp.622-640.

[9] Mirus, Rolf, R.S. Smith and V. Karoleff (1994), Canada's Underground Economy Revisited: Update and Critique, Canadian Public Policy, pp 235-252.

[10] Pissarides, C. and G. Weber, (1989), An Expenditure-Based Estimate of Britain's Black Economy, Journal of Public Economics, vol.39, pp.17-32.

[11] Ministère des Finances du Québec, (2004), Budget 2004-2005 Budget plan.

[12] Scheiner, Friedrich and Dominik H. Enste, (2000), Shadow Economies: Sizes, Causes, and Consequences, Journal of Economic Literature, Vol. XXXVIII, pp.77-114.

[13] Spiro, Peter S., (1996), "Monetary Estimates of the Underground Economy: A Critical Evaluation", The Canadian Journal of Economics, Vol. 29, pp. 5171-5175.

[14] Stock, J. H., J. H. Wright and M. Yogo, A Survey of Weak Instruments and Weak Identification in Generalized Method of Moments, Journal of Business and Economic Statistics, Vol. 20, No. 4, pp. $518-529$. 
TABLE 1: Spending and income of the sample households (in 2002 dollars)

\begin{tabular}{rrrrrrr}
\hline & \multicolumn{2}{c}{$\begin{array}{c}\text { Number of } \\
\text { households }\end{array}$} & \multicolumn{2}{c}{$\begin{array}{c}\text { Average } \\
\text { current expenditure }\end{array}$} & \multicolumn{2}{c}{$\begin{array}{c}\text { Average } \\
\text { income }\end{array}$} \\
\hline \hline Year & Total & Self-empl. & Total & Self-empl. & Total & Self-empl. \\
\hline 2002 & 970 & 105 & 44817 & 47362 & 65254 & 66586 \\
2001 & 1038 & 79 & 42530 & 50828 & 65253 & 73424 \\
2000 & 983 & 86 & 41946 & 45625 & 66522 & 67177 \\
1999 & 1030 & 111 & 39950 & 42893 & 63287 & 61935 \\
1998 & 1130 & 116 & 38679 & 37178 & 64539 & 57956 \\
1997 & 1300 & 134 & 37048 & 40042 & 61543 & 61072 \\
\hline Total & 6451 & 631 & 40589 & 43346 & 64260 & 63947 \\
\hline \hline
\end{tabular}


TABLE 2: Estimation results for the nondurable goods demand system (GMM)

\begin{tabular}{|c|c|c|c|c|c|}
\hline & Food & Alcohol & Transportation & Clothing & $\begin{array}{l}\text { Personal } \\
\text { care }\end{array}$ \\
\hline \multicolumn{6}{|l|}{ Variables } \\
\hline Constant & $\begin{array}{l}-23,144 \\
(13,935)\end{array}$ & $\begin{array}{l}11,123 \\
(5,331)\end{array}$ & $\begin{array}{c}5,876 \\
(5,260)\end{array}$ & $\begin{array}{c}2,250 \\
(3,280)\end{array}$ & $\begin{array}{l}-1,827 \\
(1,917)\end{array}$ \\
\hline 1997 & & & & & \\
\hline 1998 & $\begin{array}{l}-0,011 \\
(0,052)\end{array}$ & $\begin{array}{c}0,008 \\
(0,024)\end{array}$ & $\begin{array}{c}0,011 \\
(0,025)\end{array}$ & $\begin{array}{l}-0,017 \\
(0,020)\end{array}$ & $\begin{array}{c}0,014 \\
(0,008)\end{array}$ \\
\hline 1999 & $\begin{array}{l}-0,019 \\
(0,195)\end{array}$ & $\begin{array}{c}0,086 \\
(0,074)\end{array}$ & $\begin{array}{c}0,128 \\
(0,073)\end{array}$ & $\begin{array}{l}-0,051 \\
(0,046)\end{array}$ & $\begin{array}{c}0,055 \\
(0,028)\end{array}$ \\
\hline 2000 & $\begin{array}{l}-0,097 \\
(0,257)\end{array}$ & $\begin{array}{c}0,087 \\
(0,097)\end{array}$ & $\begin{array}{c}0,132 \\
(0,097)\end{array}$ & $\begin{array}{l}-0,117 \\
(0,060)\end{array}$ & $\begin{array}{c}0,046 \\
(0,037)\end{array}$ \\
\hline 2001 & $\begin{array}{l}-0,046 \\
(0,179)\end{array}$ & $\begin{array}{c}0,047 \\
(0,069)\end{array}$ & $\begin{array}{c}0,065 \\
(0,067)\end{array}$ & $\begin{array}{l}-0,094 \\
(0,044)\end{array}$ & $\begin{array}{c}0,055 \\
(0,026)\end{array}$ \\
\hline 2002 & $\begin{array}{l}-0,142 \\
(0,274)\end{array}$ & $\begin{array}{c}0,108 \\
(0,103)\end{array}$ & $\begin{array}{c}0,145 \\
(0,101)\end{array}$ & $\begin{array}{l}-0,126 \\
(0,063)\end{array}$ & $\begin{array}{c}0,061 \\
(0,039)\end{array}$ \\
\hline$y_{s}$ & $\begin{array}{c}0,034 \\
(1,310)\end{array}$ & $\begin{array}{c}0,366 \\
(0,523)\end{array}$ & $\begin{array}{c}0,496 \\
(0,526)\end{array}$ & $\begin{array}{l}-0,598 \\
(0,372)\end{array}$ & $\begin{array}{c}0,082 \\
(0,193)\end{array}$ \\
\hline$y_{s}^{2}$ & $\begin{array}{c}0,055 \\
(0,265)\end{array}$ & $\begin{array}{l}-0,091 \\
(0,119)\end{array}$ & $\begin{array}{l}-0,115 \\
(0,128)\end{array}$ & $\begin{array}{c}0,111 \\
(0,099)\end{array}$ & $\begin{array}{l}-0,024 \\
(0,042)\end{array}$ \\
\hline$y_{s}^{3}$ & $\begin{array}{l}-0,003 \\
(0,011)\end{array}$ & $\begin{array}{c}0,004 \\
(0,006)\end{array}$ & $\begin{array}{c}0,005 \\
(0,006)\end{array}$ & $\begin{array}{l}-0,004 \\
(0,005)\end{array}$ & $\begin{array}{c}0,001 \\
(0,002)\end{array}$ \\
\hline$Y$ & $\begin{array}{c}4,500 \\
(2,544)\end{array}$ & $\begin{array}{l}-2,067 \\
(0,973)\end{array}$ & $\begin{array}{l}-1,091 \\
(0,961)\end{array}$ & $\begin{array}{l}-0,436 \\
(0,599)\end{array}$ & $\begin{array}{c}0,342 \\
(0,350)\end{array}$ \\
\hline$Y^{2}$ & $\begin{array}{l}-0,214 \\
(0,115)\end{array}$ & $\begin{array}{c}0,096 \\
(0,044)\end{array}$ & $\begin{array}{c}0,050 \\
(0,044)\end{array}$ & $\begin{array}{c}0,023 \\
(0,027)\end{array}$ & $\begin{array}{l}-0,015 \\
(0,016)\end{array}$ \\
\hline Children 15-24 & $\begin{array}{c}0,039 \\
(0,031)\end{array}$ & $\begin{array}{l}-0,021 \\
(0,012)\end{array}$ & $\begin{array}{l}-0,012 \\
(0,012)\end{array}$ & $\begin{array}{c}0,005 \\
(0,007)\end{array}$ & $\begin{array}{l}-0,005 \\
(0,004)\end{array}$ \\
\hline Spouse's age & $\begin{array}{c}0,002 \\
(0,001)\end{array}$ & $\begin{array}{c}0,000 \\
(0,000)\end{array}$ & $\begin{array}{c}0,000 \\
(0,000)\end{array}$ & $\begin{array}{c}0,000 \\
(0,000)\end{array}$ & $\begin{array}{c}0,000 \\
(0,000)\end{array}$ \\
\hline Home owner & $\begin{array}{c}0,012 \\
(0,052)\end{array}$ & $\begin{array}{l}-0,010 \\
(0,020)\end{array}$ & $\begin{array}{l}-0,007 \\
(0,019)\end{array}$ & $\begin{array}{c}0,001 \\
(0,011)\end{array}$ & $\begin{array}{l}-0,007 \\
(0,007)\end{array}$ \\
\hline City & $\begin{array}{c}0,124 \\
(0,079)\end{array}$ & $\begin{array}{l}-0,045 \\
(0,029)\end{array}$ & $\begin{array}{l}-0,062 \\
(0,030)\end{array}$ & $\begin{array}{c}0,009 \\
(0,017)\end{array}$ & $\begin{array}{l}-0,011 \\
(0,011)\end{array}$ \\
\hline No. rooms in home & $\begin{array}{c}0,006 \\
(0,012)\end{array}$ & $\begin{array}{l}-0,001 \\
(0,005)\end{array}$ & $\begin{array}{l}-0,001 \\
(0,005)\end{array}$ & $\begin{array}{l}-0,003 \\
(0,003)\end{array}$ & $\begin{array}{c}0,004 \\
(0,002)\end{array}$ \\
\hline Car & $\begin{array}{l}-0,193 \\
(0,091)\end{array}$ & $\begin{array}{c}0,048 \\
(0,035)\end{array}$ & $\begin{array}{c}0,143 \\
(0,033)\end{array}$ & $\begin{array}{l}-0,018 \\
(0,022)\end{array}$ & $\begin{array}{l}-0,006 \\
(0,013)\end{array}$ \\
\hline$\kappa_{1}$ & $\begin{array}{c}1,193 \\
(0,154)\end{array}$ & & & & \\
\hline$\kappa_{2}$ & $\begin{array}{r}-0,118 \\
0,016\end{array}$ & & & & \\
\hline Sargan-Hansen test: 42.2 & & & & & \\
\hline
\end{tabular}


TABLE 3: Trends in the weight of income from self-employment in Quebec's GDP (in millions of dollars)

\begin{tabular}{cccc}
\hline \multicolumn{3}{c}{ Quebec } \\
\hline \hline Year & GDP & $\begin{array}{c}\text { Self-empl. } \\
\text { earnings }\end{array}$ & $\begin{array}{c}\text { Proportion GDP } \\
\text { from s-e earnings }\end{array}$ \\
\hline 1997 & 188424 & 11759 & $6,2 \%$ \\
1998 & 196258 & 12082 & $6,2 \%$ \\
1999 & 210166 & 12669 & $6,0 \%$ \\
2000 & 224165 & 12981 & $5,8 \%$ \\
2001 & 229617 & 13733 & $6,0 \%$ \\
2002 & 242914 & 14541 & $6,0 \%$ \\
\hline \hline
\end{tabular}

TABLE 4: Trends in the share of self-employment earnings in Canada's GDP (in millions of dollars)

\begin{tabular}{cccc}
\hline \multicolumn{3}{c}{ Canada } \\
\hline \hline Year & GDP & $\begin{array}{c}\text { Self-empl. } \\
\text { earnings }\end{array}$ & $\begin{array}{c}\text { Proportion GDP } \\
\text { from s-e earnings }\end{array}$ \\
\hline 1997 & 882733 & 56326 & $6,4 \%$ \\
1998 & 914973 & 59660 & $6,5 \%$ \\
1999 & 980524 & 63286 & $6,5 \%$ \\
2000 & 1064950 & 65720 & $6,2 \%$ \\
2001 & 1092246 & 69523 & $6,4 \%$ \\
2002 & 1142123 & 74013 & $6,5 \%$ \\
\hline \hline
\end{tabular}

TABLE 5: Estimation of the size of the underground economy

\begin{tabular}{ccc}
\hline \hline Year & $\begin{array}{c}\text { Underground ecn. } \\
\text { (\% of GDP) }\end{array}$ & $\begin{array}{c}\text { Confidence } \\
\text { interval (5\%) }\end{array}$ \\
\hline \hline 1997 & $4,62 \%$ & {$[4,58 ; 4,66]$} \\
1998 & $5,40 \%$ & {$[5,36 ; 5,44]$} \\
1999 & $5,55 \%$ & {$[5,51 ; 5,59]$} \\
2000 & $5,49 \%$ & {$[5,45 ; 5,53]$} \\
2001 & $5,72 \%$ & {$[5,68 ; 5,76]$} \\
2002 & $5,69 \%$ & {$[5,65 ; 5,73]$} \\
\hline \hline
\end{tabular}

TABLE 6: Household spending in Quebec's underground economy

\begin{tabular}{cccc}
\hline \hline Year & Share of GDP & $\begin{array}{c}\text { Expenditures by household } \\
\text { (in dollars) }\end{array}$ & $\begin{array}{c}\text { Confidence } \\
\text { interval (95\%) }\end{array}$ \\
\hline \hline 1997 & $4,62 \%$ & 2842 & {$[2815 ; 2865]$} \\
1998 & $5,40 \%$ & 3428 & {$[3400 ; 3452]$} \\
1999 & $5,55 \%$ & 3731 & {$[3703 ; 3758]$} \\
2000 & $5,49 \%$ & 3894 & {$[3863 ; 3921]$} \\
2001 & $5,72 \%$ & 4119 & {$[4090 ; 4149]$} \\
2002 & $5,69 \%$ & 4319 & {$[4288 ; 4350]$} \\
\hline \hline
\end{tabular}


TABLE 7: Tax cost to the government of Quebec of the underground economy

\begin{tabular}{cccc}
\hline \hline Year & $\begin{array}{c}\text { Tax rate } \\
\text { annual average }\end{array}$ & $\begin{array}{c}\text { Tax leakage } \\
\text { (billions of dollars) }\end{array}$ & $\begin{array}{c}\text { Confidence } \\
\text { interval (5\%) }\end{array}$ \\
\hline \hline 1997 & $15,40 \%$ & 2,04 & {$[2,02 ; 2,06]$} \\
1998 & $16,80 \%$ & 2,63 & {$[2,61 ; 2,65]$} \\
1999 & $17,70 \%$ & 3,00 & {$[2,98 ; 3,02]$} \\
2000 & $18,40 \%$ & 3,25 & {$[3,23 ; 3,28]$} \\
2001 & $17,00 \%$ & 3,29 & {$[3,26 ; 3,31]$} \\
2002 & $15,50 \%$ & 3,25 & {$[3,23 ; 3,28]$} \\
\hline \hline
\end{tabular}




\section{Appendix 1- Definition of the expenditure and consumption variables}

The model's expenditure and consumption variables are expressed as the ratio of the amount spent on each category of good to total expenditure on nondurables. The estimates are on food, alcoholic beverages, transportation, clothing, and personal care (recreational spending falls into the residual category).

Food includes purchases in a store or restaurant, and allowances paid for day board and children's lunches.

Alcoholic beverages include those purchased at the store and those consumed in a licensed establishment, as well as those products used in home brewing of alcoholic beverages.

The variable transportation includes spending on fuel for the vehicle, trucks, and recreational vehicles owned or rented.

Clothing purchases include laundering and dry-cleaning services and washing and drying in Laundromats as well as the cost of self-service dry-cleaning. In addition, clothes, athletic shoes, accessories (gloves, scarves, etc.), and watches for individuals aged four and over belonging to the household. Gifts of clothes to children aged three or younger, fabric and sewing supplies used for the production of garments, and the services of tailors and seamsters are also part of the household's clothing expenditures.

Finally, the item personal care includes spending on healthcare, dental, disposable diapers, hairdressing, other personal care services (depilation, manicures, facials, and tanning salons), hair care products, dyes and rinses and other personal care supplies such as hair brushes, scissors, etc. Expenditures on electrical hairstyling equipment and personal care (hair dryer, razor, etc.) also fall under this item. 